\title{
Active antibacterial coating of cotton fabrics with antimicrobial proteins
}

\author{
Amy Y. Xu (iD) - Duncan J. McGillivray (D) Andrew J. Dingley (1)
}

Received: 4 November 2020/Accepted: 10 June 2021/Published online: 22 June 2021

(C) The Author(s) 2021

\begin{abstract}
The prevention of bacteria colonization by immobilizing proteins with antimicrobial activity onto cotton fabrics was investigated. Such coatings have potential applications in medical dressing materials used in wound care and healing. Two antimicrobial proteins lysozyme and hydramacin-1 (HM-1) were surface immobilized through two linkers (3-aminopropyl) triethoxysilane (APTES) and citric acid in the presence of the water soluble carbodiimide coupling reagent 1-cyclohexyl-3-(2-morpholinoethyl)carbodiimide metho-p-toluenesulfonate. Surface composition analysis by attenuated total reflection-Fourier transform infrared and X-ray photoelectron spectroscopies confirmed formation of the protein-cellulose conjugates. Antimicrobial activities of the different
\end{abstract}

Supplementary Information The online version contains supplementary material available at https://doi.org/10.1007/ s10570-021-03997-2.

A. Y. Xu · D. J. McGillivray

School of Chemical Sciences, The University of Auckland, Private Bag 92019, Auckland 1142, New Zealand

A. Y. Xu

Department of Chemistry, Louisiana State University, Baton Rouge, LA 70803, USA

D. J. McGillivray

The MacDiarmid Institute, Victoria University of

Wellington, PO Box 600, Wellington 6140, New Zealand functionalized surfaces were found to vary between APTES and citric acid directed coatings. Citric acid immobilized lysozyme treated samples demonstrated superior activity against Gram-positive Bacillus subtilis, whereas APTES immobilized HM-1 treated samples demonstrated an advantage in inhibiting the growth of Gram-negative Escherichia coli. The antibacterial activity and stability of citric acid immobilized protein fabrics following sonication, boiling and chemical treatment were noticeably higher than that of the corresponding APTES immobilized protein fabrics. The dual coating of fibers with both antimicrobial proteins afforded efficient antimicrobial activities against both bacterial species. The results suggest that coating cotton fibers with antimicrobial proteins and peptides represents a feasible approach for developing active surfaces that prohibit growth and colonization of bacterial strains and can be potentially used in medical cotton-based fabrics.

\footnotetext{
A. J. Dingley $(\bowtie)$

Institute of Biological Information Processing (IBI-7:

Structural Biochemistry), Forschungszentrum Jülich, Leo-

Brandt-Straße, 52425 Jülich, Germany

e-mail: a.dingley@fz-juelich.de
}
A. J. Dingley
Institut für Physikalische Biologie, Heinrich-Heine-
Universität Düsseldorf, Universitätsstraße 1,
40225 Düsseldorf, Germany 
Keywords Antibacterial - Antimicrobial proteins · Cotton $\cdot$ Surface immobilization

\section{Introduction}

The transmission of infectious diseases in healthcare facilities is an important issue in society (Davis et al. 2014; Jiang et al. 2018a). Microorganisms colonize textile materials and plastics, and the transmission of these organisms occurs readily via surface contact with hands, fabrics and hospital devices (Katoh et al. 2019; Tanabe et al. 2020). Moreover, the formation of biofilms on surfaces, such as medical implants (Arciola et al. 2018; Davidson et al. 2019), has been shown to have a considerable negative impact on human health.

Textile fabrics prepared from cotton are used widely in medical products and are prone to contamination by bacteria because cotton provides an ideal surface medium for microbial growth, and therefore represents a potential health risk (Chiereghin et al. 2020). To overcome this issue, a wide range of compounds that furnish antimicrobial functionality to cotton textiles have been examined, ranging from organic compounds such as triclosan and betaine (Duan et al. 2020; Emam 2019), through to inorganic ions (Morais et al. 2016) and natural plant dyes (Yilmaz 2020; Yılmaz and Bahtiyari 2020; Yılmaz et al. 2020). In particular, the use of inorganic ions, such as $\mathrm{Ag}, \mathrm{Au}, \mathrm{Cu}, \mathrm{Ti}$ and $\mathrm{Zn}$ based nanoparticles, are used extensively in the formulation of health care products (Jiang et al. 2018b; Tan et al. 2019; Weir et al. 2012). Nonetheless, there is evidence that inorganic materials and particular chemicals may be toxic to humans (Rovira and Domingo 2019; Schrand et al. 2010), and thus, alternative compounds are in demand. Moreover, some compounds show activity over a limited range of conditions, which precludes their broad use. An alternative approach involves coating or dying materials with a synthetic or natural compound that displays innate antimicrobial properties (Hyldgaard et al. 2014; Lin et al. 2018; Oda et al. 2011; Sobczak et al. 2013; Yang et al. 2020). Among others, antimicrobial peptides and proteins, which are part of the endogenous immune response in organisms, provide direct local protection against microbial infections (Battersby et al. 2016; Yeaman and Yount
2003). Antimicrobial proteins and peptides are recognized as potential novel antibacterial agents, because they are effective against a broad spectrum of pathogens, including multi-drug resistant bacteria (Malik et al. 2016). Most antimicrobial proteins and peptides function by interacting with the surface of bacteria to either permeabilize the membrane layers or to translocate across the membrane bilayers to interact and disrupt the function of cytoplasmic targets (Malik et al. 2016; Yeaman and Yount 2003).

Studies have shown the potential therapeutic value of antimicrobial proteins and peptides (Seo et al. 2012; Torres et al. 2019). In particular, research has focused on the development of topically applied antimicrobial protein and peptide-derived agents, such as wound dressings and creams (Mangoni et al. 2016), because of the relative safety of topical therapies, and the issues associated with the potential long-term toxicology and immunogenicity of any new class of antimicrobial protein or peptide-derived drug administered systematically. Moreover, these biomolecules may be better suited than low molecular weight antimicrobial compounds such as conventional antibiotics, or potentially ecotoxic inorganic coatings (e.g., colloidal metal particles) for use in coating medical materials because of reduced likelihood of selection for microbial resistance and ability to modulate the host immune response (Hale and Hancock 2007; Magana et al. 2020). In addition, strategies to modify native antimicrobial proteins and peptides to improve their activity, stability and half-life, such as the use of D- or nonnatural amino acid substitutions, peptidomimetics, cyclization and chemical modifications (e.g., lipidation, PEGlyation), further increase their potential as therapeutics against infectious diseases (Kuppusamy et al. 2019; Li et al. 2021).

In this study, two antibacterial proteins, lysozyme and hydramacin-1 (HM-1), were used to coat cotton fibers. Lysozyme was chosen because of its wellknown bactericidal properties, high thermal stability (Li-Blatter and Seelig 2019; Vilcacundo et al. 2018), wide $\mathrm{pH}$ activity range and US Food and Drug Administration authorized use as a natural antibacterial agent, whereas HM-1 was selected because of the high stability afforded by the four disulfide bonds and broad, specific antibacterial activity (Jung et al. 2009). Moreover, the proteins function differently; lysozyme is an enzyme and HM-1 disrupts membrane integrity by interacting with the bacterial membrane to cause 
aggregation of cells. In combination, these two antimicrobial proteins should be effective against Gram-positive and Gram-negative bacteria, and HM-1 has been shown to be effective against some clinical isolates and multi-resistant strains (Jung et al. 2009). There are several ways of immobilizing proteins onto surfaces (Mohamad et al. 2015). While direct anchorage onto desired surfaces is the simplest approach, significant loss of activity is often observed because of surface-induced conformational changes and reduced dynamics once proteins are tethered onto the solid support (Faccio 2018; Mukherjee and Gupta 2015; Xiao et al. 2018). Therefore, a linker or spacer is often inserted between the protein and the surface to retain activity of the protein once immobilized on the surface (Akers et al. 2017; Balamurugan et al. 2008; Gunda et al. 2014; Wu et al. 2018). Previously, Edwards et al. demonstrated the use of citric acid and (3-aminopropyl) triethoxysilane (APTES) as linkers for the immobilization of lysozyme onto cotton surfaces (Edwards et al. 2011). In this study, we adopted this chemistry and coated cotton surfaces with lysozyme and HM-1. The protein-coated cellulose fibers were characterized by Fourier-transform infrared spectroscopy (FTIR), X-ray photoelectron spectroscopy (XPS), scanning electron microscopy (SEM) and environmental scanning electron microscopy, and these fibers displayed microbial activity against Gram-positive Bacillus subtilis (B. subtilis) and Gram-negative Escherichia coli (E. coli).

\section{Experimental}

\section{Materials}

Cotton fabrics (bleached, desized, mercerized, $109 \mathrm{~g} \mathrm{~m}^{-2}$ ) were purchased from Testfabrics Inc. (item number: 1403002; West Pittston, PA, USA). Lysozyme from chicken egg white (L6876), APTES (A3648), citric acid $(251,275)$, sodium hypophosphite $(243,663)$ and N-cyclohexyl-N'-(2-morpholinoethyl) carbodiimide methyl-p-toluenesulfonate (CMCS; C106402) were purchased from Sigma-Aldrich (St Louis, MO, USA). Recombinant HM-1 was produced recombinantly and purified as described previously (Jung et al. 2009). The purity and molecular mass of recombinant HM-1 was confirmed by SDS-PAGE and mass spectrometry analysis.
APTES coupling

APTES was added to $75 \%(\mathrm{v} / \mathrm{v})$ ethanol to a final concentration of $5 \%$ (w/w) (Fig. S1). The $\mathrm{pH}$ of the solution was adjusted to five using concentrated acetic acid (99.5\%) and stirred for $1 \mathrm{~h}$. Based on previous approaches to add silane coupling agents to cellulose (Castellano et al. 2004; Frone et al. 2018), cotton swatches $\left(5 \mathrm{~cm}^{2}\right.$ in size $)$ were incubated in the APTES solution for $1 \mathrm{~h}$ and cured at $110^{\circ} \mathrm{C}$ for $1 \mathrm{~h}$ (Fig. S1). Samples were rinsed thoroughly with $75 \%$ (v/v) ethanol to remove excess APTES and dried overnight. CMCS chemistry has been reported to afford higher yields of conjugated products when compared with the commonly used 1-ethyl-3-(3-dimethylaminopropyl)carbodiimide/ $N$-hydroxysuccinimide coupling approach (Wittmann and Hock 1989). Thus, we selected CMCS to facilitate the amide and carboxylic acid conjugation. Different combinations of CMCS and lysozyme concentrations were tested to determine the optimal conditions for coupling to the APTESactivated cotton fibers. Both CMCS and lysozyme were dissolved in $50 \mathrm{mM}$ sodium phosphate buffer ( $\mathrm{pH}$ 4.7). The final concentration range of CMCS was 24-330 $\mathrm{mM}$ and the protein concentration ranged between 35 and $700 \mu \mathrm{M}$. The solution $\mathrm{pH}$ was adjusted to seven when both CMCS and lysozyme were fully dissolved. Finally, pre-treated cotton swatches were incubated in solutions with CMCS and lysozyme for $20 \mathrm{~h}$ at $4{ }^{\circ} \mathrm{C}$ (Fig. S1). Cotton swatches were washed thoroughly with PBS to remove protein that may be physiosorbed. The optimized CMCS and lysozyme concentrations were used for the HM-1/CMCS coupling reaction.

\section{Citric acid coupling}

An aqueous solution containing 7\% (w/w) citric acid and $5 \%(\mathrm{w} / \mathrm{w})$ sodium hypophosphite was prepared. Based on previous methods (El-Tahlawy et al. 2007; Fouda and Fahmy 2011; Meftahi et al. 2018) (Fig. S2, top), cotton swatches $\left(5 \mathrm{~cm}^{2}\right.$ in size) were soaked thoroughly in this solution for $2 \mathrm{~h}$ and dried in Petri dishes for $5 \mathrm{~min}$ at $80{ }^{\circ} \mathrm{C}$ to remove excess water. Dried swatches were cured at $160{ }^{\circ} \mathrm{C}$ for $3 \mathrm{~min}$. Different combinations of CMCS and lysozyme concentrations were tested to determine the optimal conditions for coupling to the citric acid-activated cotton fibers. The CMCS solution was prepared by 
dissolving CMCS in $50 \mathrm{mM}$ sodium phosphate buffer ( $\mathrm{pH}$ 4.7). Cotton swatches pretreated with citric acid were incubated in the CMCS solution for $30 \mathrm{~min}$ at concentrations ranging between 6 and $95 \mathrm{mM}$. Activated swatches were washed thoroughly with PBS to remove physiosorbed acid on the surface. Lysozyme was dissolved in $50 \mathrm{mM}$ phosphate buffer ( $\mathrm{pH} 7$ ). Activated cotton swatches were then incubated at different protein concentrations ranging between 9 and $140 \mu \mathrm{M}$ for $20 \mathrm{~h}$ at $4{ }^{\circ} \mathrm{C}$ (Fig. S2, bottom). Cotton swatches were washed thoroughly with PBS. The optimal CMCS and lysozyme concentrations found were used for the HM-1/CMCS coupling reaction. The approximate amount of lysozyme bound to the cotton swatches was determined by measuring the absorbance of the protein solution at $280 \mathrm{~nm}$ before and after surface immobilization. The change in the absorbance of the protein sample and the molar extinction coefficient of the protein were used to estimate the amount of protein bound.

\section{ATR-FTIR spectrometry}

Attenuated total reflection-FTIR (ATR-FTIR) was carried out using a Bruker ALPHA-Platinum FTIR spectrometer (Billerica, MA, USA) equipped with a platinum diamond ATR crystal. Samples were dried for $30 \mathrm{~s}$ by passing a stream of air across the surface to remove moisture prior to ATR-FTIR measurement. Each spectrum was collected both on treated and untreated cotton samples by cumulating 32 background and 32 sample scans per sample with a resolution of $1 \mathrm{~cm}^{-1}$ and a wavenumber range of $4000-400 \mathrm{~cm}^{-1}$.

\section{XPS analysis}

The XPS measurements were performed by using a Scienta Omicron ESCA2SR X-ray photoelectron spectroscope system equipped with a Flood Source Charge Neutralizer (Scienta Omicron Inc., Denver, CO, USA). The samples were fixed on the sample stage with double-sided carbon tape and loaded into the XPS preparation chamber and pumped for more than $8 \mathrm{~h}$ before transfer to the analysis chamber. Analyses were carried out with a Mono $\mathrm{Al} \mathrm{K} \alpha$ X-ray source $(1486.6 \mathrm{eV})$ at $450 \mathrm{~W}$ and the pressure was maintained below $3 \times 10^{-9}$ Torr. A survey scan and all elemental region scans were performed for each sample. Data were post-processed with Casa XPS software, and spectra were calibrated with the C-1 s peak at $284.8 \mathrm{eV}$. Core level XPS spectra were deconvoluted to obtain chemical state information.

Antimicrobial assay

Antimicrobial activities of protein immobilized cotton fabrics were tested against both Gram-positive $B$. subtilis (ATCC6633) and Gram-negative E. coli (K12W3110) bacteria strains using an established method (Edwards et al. 2011). Bacterial colony forming units (CFU) were determined from spectroscopic readings at $600 \mathrm{~nm}\left(\mathrm{OD}_{600}\right)$ (Campbell 2011; Penuelas-Urquides et al. 2013). Based on constructed standard curves of $\mathrm{OD}_{600}$ against $\mathrm{CFU}$, the conversion factors for B. subtilis and E. coli were calculated to be $1 \times 10^{6}$ and $1 \times 10^{8} \mathrm{CFU} / \mathrm{mL}$ per $\mathrm{OD}_{600}$, respectively.

Overnight cell cultures were prepared by inoculating a single bacteria colony into Luria Bertani (LB) medium. Two-hundred microliters of the overnight cell culture was transferred to $20 \mathrm{~mL}$ fresh $\mathrm{LB}$ medium and incubated at $37{ }^{\circ} \mathrm{C}$ with shaking at $180 \mathrm{rpm}$ until the $\mathrm{OD}_{600}$ reached 0.6 (log phase). Cells were harvested by centrifugation for $30 \mathrm{~min}$ at $4500 \mathrm{~g}$ and $25{ }^{\circ} \mathrm{C}$. Cell pellets were washed three times using sterile normal saline $(0.90 \% \mathrm{w} / \mathrm{v} \mathrm{NaCl}, \mathrm{pH} 7.0)$ to remove growth media. Cells were diluted with sterile normal saline to an initial population of 1.1-1.7 $\times 10^{6} \mathrm{CFU} / \mathrm{mL}$ for the assays with $B$. subtilis and $0.9-1.8 \times 10^{8} \mathrm{CFU} / \mathrm{mL}$ for the assays with E. coli. Surface modified cotton swatches $\left(2.5 \mathrm{~cm}^{2}\right)$ were placed in vials containing $3 \mathrm{~mL}$ of the cell suspension. A plain cotton swatch was used as a control. Cell cultures were incubated at $37{ }^{\circ} \mathrm{C}$ with shaking at $100 \mathrm{rpm}$. Aliquots $(100 \mu \mathrm{L})$ of the cell culture were collected at several time points for 5-7 h. The cell population for each treatment was normalized against the control sample and was calculated as $[\mathrm{A}]^{\mathrm{s}} /$ $[\mathrm{A}]^{\mathrm{r}}$, where $[\mathrm{A}]^{\mathrm{s}}$ is the $\mathrm{OD}_{600}$ reading of the cell culture incubated with surface treated cotton fabrics measured at different times and $[\mathrm{A}]^{\mathrm{r}}$ is the $\mathrm{OD}_{600}$ reading of the cell culture incubated with the control cotton swatches without treatment.

\section{Scanning electron microscopy}

Scanning electron microscopy (SEM) was used to examine changes in surface morphology of the 
swatches after treatments. SEM specimens were dried by passing a gentle stream of air across the cotton swatch surface for $2 \mathrm{~min}$. Dried swatches were cut into desired sizes and immobilized onto stainless steel stubs using double-sided tape. Since cotton fabrics are insulators, a thin layer of platinum was coated onto the sample by physical vapor deposition using a Quorum Q150RS sputter coater. SEM examination was performed on a Philips XL30S FEG scanning electron microscope (Philips, Amsterdam, The Netherlands) with an accelerating voltage of $5.0 \mathrm{kV}$. For each sample, photos were taken from five randomly selected areas at each magnification.

\section{Environmental scanning electron microscopy}

Environmental scanning electron microscopy (ESEM) was used to observe changes in cell morphology upon exposure to surface treated cotton samples. Cotton swatches with different surface treatments were incubated with both $B$. subtilis and $E$. coli cell suspensions at populations of $6 \times 10^{5}$ and $6 \times 10^{7} \mathrm{CFU} / \mathrm{mL}$, respectively, prepared in sterilized saline solutions $(0.90 \% \mathrm{w} / \mathrm{v} \mathrm{NaCl}, \mathrm{pH} 7.0)$ for up to $6 \mathrm{~h}$ at $37{ }^{\circ} \mathrm{C}$ with shaking at $100 \mathrm{rpm}$. Bacteria-containing cotton samples were washed gently with sterilized ultra-pure water to remove excess salt, which can convolute images. Samples, without fixing, were mounted onto double-sided carbon tape on top of the stainless-steel stubs. Images were acquired using an FEI Quanta 200 microscope (Hillsboro, Oregon, USA) equipped with a Schottky field emission gun with an accelerating voltage of $10 \mathrm{kV}$. For each sample, photos were taken from five randomly selected areas at each magnification and representative images are presented.

Stability tests of surface functionalized cotton swatches

To model cleaning/sterilization procedures for dressing materials, swatches were subjected to three different treatments: sonication, heating and soaking in alcohol. Cleaning by sonication (Elmasonic S30 bath sonicator, Singen, Germany) was carried out by treating the cotton swatch for $30 \mathrm{~min}$ at $80 \mathrm{~W}$ followed by rinsing with phosphate saline buffer three times. Heating involved boiling the cotton swatches in water for $60 \mathrm{~s}$. The alcohol soaking process was performed by incubating the swatches in $70 \%$ ethanol (v/v) aqueous solution for $10 \mathrm{~min}$ followed by three repeat soaks and rinses in PBS buffer. The surface properties and antimicrobial activities of the treated surfaces were examined using SEM and the antimicrobial assay.

\section{Results}

Optimal coupling reagent and protein concentrations for antimicrobial activity

The optimal coupling reagent amount and lysozyme concentration for maximum antibacterial activity were tested using the antimicrobial activity assay with B. subtilis. Using a fixed CMCS:protein ratio of 20:1, various protein concentrations were tested to determine the lowest protein concentration required while maintaining antibacterial activity. For both the citric acid and APTES coupling reactions the optimal CMCS concentration was $2 \mathrm{mg}$ per $1 \mathrm{~cm}^{2}$ of cotton swatch and a lysozyme concentration of $35 \mu \mathrm{M}$ (Fig. S3). Although the HM-1 coupling reaction may be optimal under different conditions, bacterial growth was inhibited by $180 \mathrm{~min}$ when using lysozyme over the range of 8-140 $\mu \mathrm{M}$ (Fig. S3). Thus, we anticipated that working with $\mathrm{HM}-1$ at similar concentrations would give active surfaces and did not conduct the assay using HM-1 because of the limited amount of recombinant protein available. Based on the absorbance readings at $280 \mathrm{~nm}$ of the protein samples incubated with the cotton swatch before and after the coupling reaction and by geometric calculation using the cotton swatch size, the estimated amount of lysozyme bound in the citric acid coupling reaction was $0.5 \mathrm{mg}$ per $1 \mathrm{~cm}^{2}$ of cotton swatch. Negligible change in absorbance was observed for the APTES coupling reaction, indicating that only a small amount of protein was immobilized to the APTES coated surface, which corroborates the results observed by Edwards et al. (2011).

ATR-FTIR spectrometry confirms the immobilization of protein to the cotton fibers

ATR-FTIR spectra $\left(4000-400 \mathrm{~cm}^{-1}\right)$ were recorded for samples modified with APTES, citric acid and lysozyme after each step of surface modification (Figs. 1 and S4) to show that the proteins were 
successfully immobilized onto the cotton surface using either APTES or citric acid as chemical linkers. Characteristic features of the plain cotton spectrum are described in Figure S4 and these features are also observed for the modified cotton samples. For example, the broad band from $3600-3000 \mathrm{~cm}^{-1}$ corresponds to the hydroxyl groups involved in intra- and interchain hydrogen bonding within cellulose (Yue et al. 2015). The new peak in the FTIR spectrum following APTES treatment at $1559 \mathrm{~cm}^{-1}$ was assigned to bending vibrations of the primary $-\mathrm{NH}_{2}$, indicating that APTES successfully bonded to the cotton surface (Fig. 1a) (Edwards et al. 2011). The characteristic $\mathrm{Si}-\mathrm{O}-\mathrm{Si}$ and $\mathrm{Si}-\mathrm{O}-$ cellulose peaks at $1200-1100 \mathrm{~cm}^{-1}$ were masked by the strong peaks arising from the $\mathrm{C}-\mathrm{O}-\mathrm{C}$ vibrations in cellulose (1200-1000 $\mathrm{cm}^{-1}$; Figs. 1a and S4) (Fernandes et al. 2013). Following immobilization of lysozyme to the APTES activated surface, a new peak at $1638 \mathrm{~cm}^{-1}$ was observed and represents the amide I band (i.e., $\mathrm{C}=\mathrm{O}$ and $\mathrm{C}-\mathrm{N}$ stretching frequencies of the backbone amide bond of lysozyme), indicating the successful immobilization of lysozyme onto cotton swatches. The amide II band arising from the peptide backbone of lysozyme ( $\mathrm{N}-\mathrm{H}$ in-plane bending and $\mathrm{C}-\mathrm{N}$ and $\mathrm{C}-\mathrm{C}$ stretching vibrations) in the APTES treated cotton spectrum is visible as a weaker peak at $\sim 1550 \mathrm{~cm}^{-1}$. The FTIR spectrum of the APTES treated cotton incubated with only lysozyme suggested that a negligible amount of protein was physiosorbed (Fig. 1a).

As reported previously (Edwards et al. 2002), the peak at $1716 \mathrm{~cm}^{-1}$ in the FTIR spectrum of citric acid (CA) treated cotton likely arises from the carboxylates of citrate (Fig. 1b), indicating that citric acid was bonded to the surface of cotton fibers. The appearance of the amide I $\left(1650 \mathrm{~cm}^{-1}\right)$ band following incubation of lysozyme with the citric acid coated cotton fibers in the presence of CMCS indicated that protein immobilization was achieved. The broad band at $1510-1580 \mathrm{~cm}^{-1}$ following immobilization of lysozyme is assigned to the amide II band, whereas the concomitant changes in intensity for peaks at $1716 \mathrm{~cm}^{-1}$ (this peaks shifts to $1733 \mathrm{~cm}^{-1}$ when lysozyme is present) and $1578 \mathrm{~cm}^{-1}$ has been previously ascribed to possible amide bond stretching between the carbonyl citrate and protein amino groups ( $\mathrm{N}$-terminus and lysine side chain $\varepsilon$ amino groups) (Edwards et al. 2011). Amide I and II bands were also observed in the FTIR spectrum of the citric acid

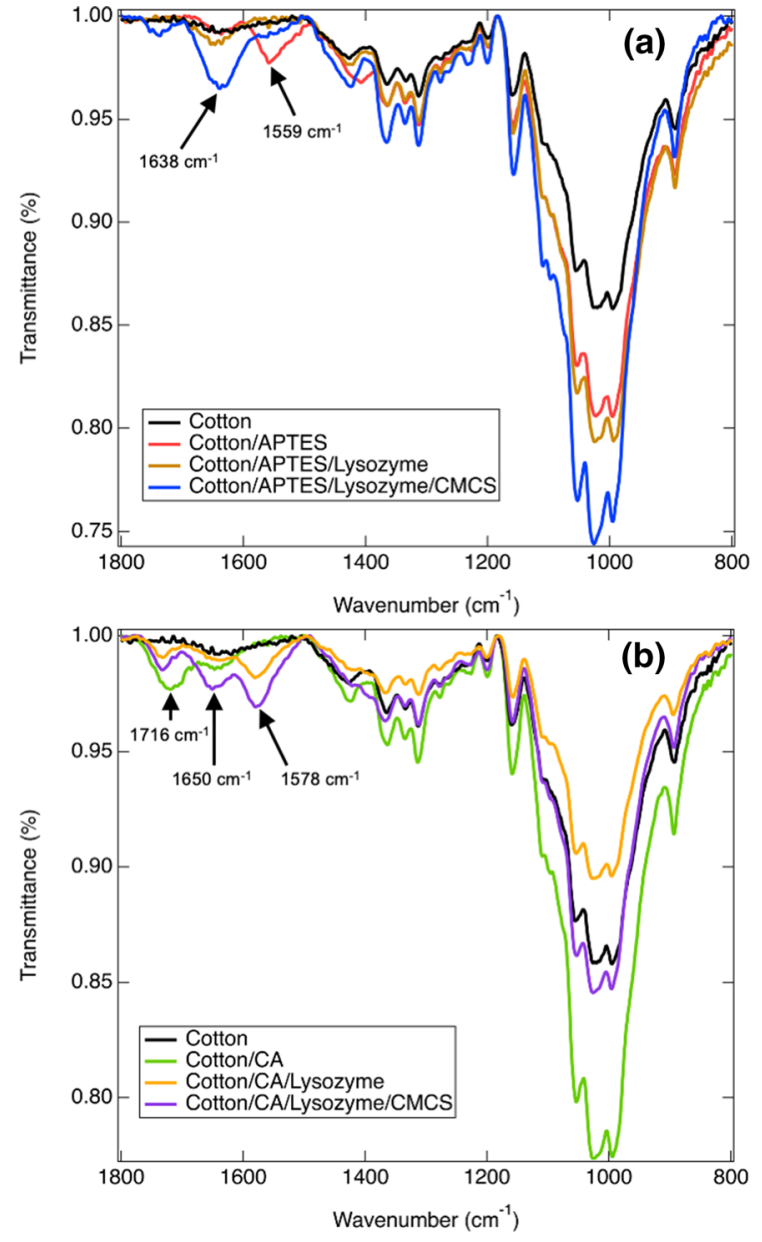

Fig. 1 The $1800-800 \mathrm{~cm}^{-1}$ region of ATR-FTIR spectra of cotton swatches treated with a APTES and lysozyme and $\mathbf{b}$ citric acid (CA) and lysozyme in the absence and presence of the coupling agent CMCS

treated swatch incubated with only lysozyme, indicating that some lysozyme was physiosorbed (Fig. 1b).

Further chemical characterization of the APTES treated samples was carried out using XPS (Fig. 2). Chemical composition analysis of the plain cotton confirmed the presence of $\mathrm{O}$ and $\mathrm{C}$ as the main constituent elements of cellulosic fibers. The $\mathrm{O} / \mathrm{C}$ ratio of plain cotton was 0.60 and lower than the theoretical ratio of pure cellulose (0.83), probably because of impurities and contamination. In addition to the O1-s (532 eV) and C1-s (287 eV) peaks, a small amount of silicon was observed ( $\mathrm{Si}-2 \mathrm{p}, 101 \mathrm{eV})$ because of the presence of doped silicon in the carbon tape that was used to fix the loosely-knitted fabric samples. 

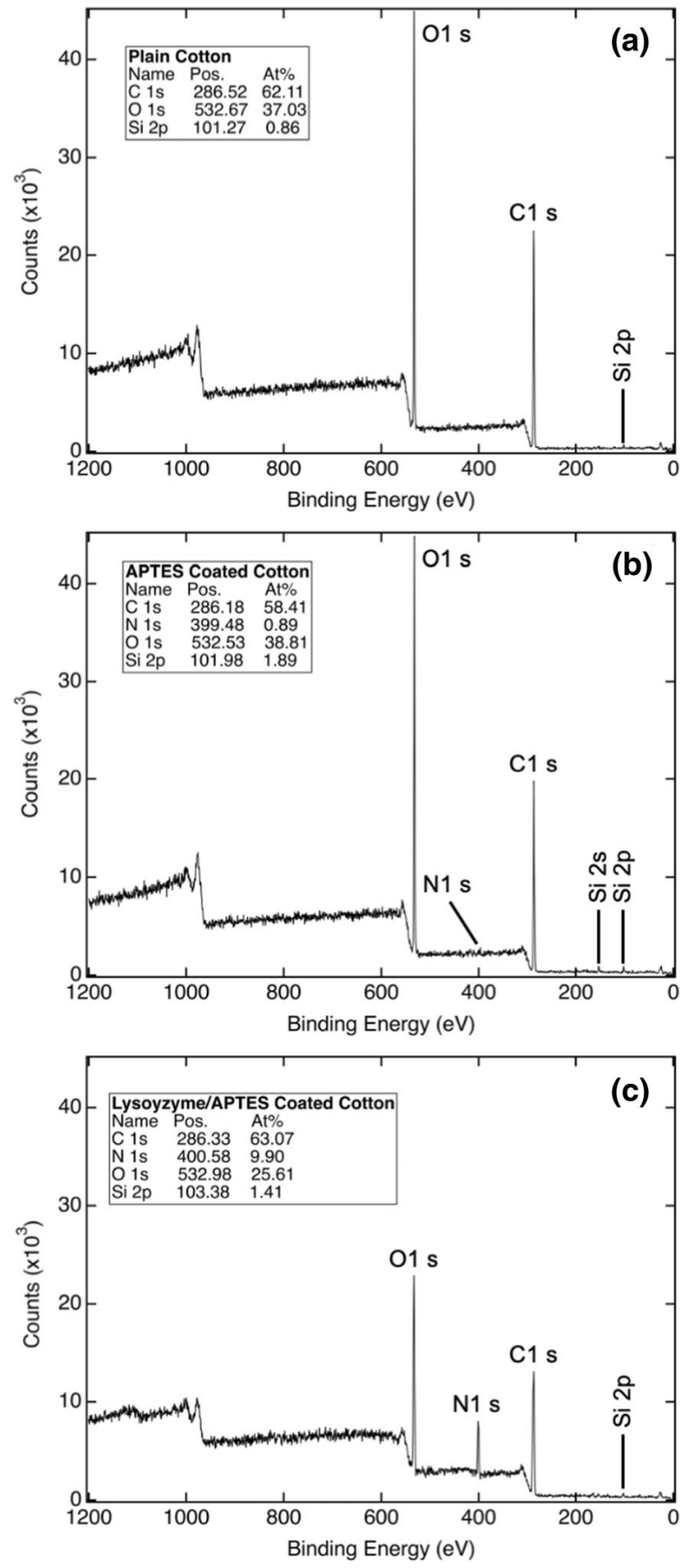

Fig. 2 XPS spectra of plain cotton and cotton swatches treated with APTES and lysozyme. a Survey spectrum of plain cotton. The weak Si peak arises from doped silicon in the carbon tape used to fix the loosely-knitted fabric samples. b Survey spectrum of APTES treated cotton surface showing the presence of Si from APTES. c Survey spectrum of lysozyme and APTES treated cotton fibers. Lysozyme immobilization caused an increase in $\mathrm{N}$ content
Increases in $\mathrm{Si}$ (Si-2p and Si-2 s, $150 \mathrm{eV}$ ) and N (N1-s, $399 \mathrm{eV})$ contents were observed for the APTES coating, indicating successful coating of the cotton swatch with APTES (Fig. 2b). Although the $\mathrm{N}$ content is low, the value is in agreement with a previous study that coated cotton with APTES to immobilize lysozyme (Edwards et al. 2011) and indicates that an APTES coating formed. Immobilization of lysozyme to APTES treated cotton in the presence of CMCS yielded a further increase in $\mathrm{N}$ content (Fig. 2c).

We also examined the wettability of the coated swatches by measuring the contact angle of the cotton treated swatches. Here, ultrapure water droplets of 5-20 $\mu \mathrm{L}$ were carefully pipetted (from $0.5 \mathrm{~cm}$ above) onto each swatch sample. The water droplets were observed to soak directly into the cotton fabrics (data not shown) because the fabric was loosely knitted (weight: $\sim 109 \mathrm{~g} \mathrm{~m}^{-2}$ ) and, except for the silane coating (Makowski 2020), the prepared surfaces are hydrophilic because the fabrics were coated with proteins and citric acid.

SEM surface morphology analysis reveals distinct changes in the surface structures

SEM was used to examine the surface morphology changes upon treatment of the cotton fiber surfaces with the cross-linking compounds and antimicrobial proteins. Visual inspection of the SEM images of the cotton surfaces with different treatments revealed changes to the surface morphology (Fig. 3). The native cotton had a highly textured micro-scale fiber appearance (Fig. 3a,b). A smoother, less textured finish to the cotton fibers was observed following APTES treatment (Fig. 3c). Regions of the cotton fibers showed defects (Fig. 3d), suggesting that the APTES coating reaction affected the surface structure of the cotton fibers, which may be further compromised following various cleaning and sterilization treatments. Cotton fibers cross-linked with citric acid (Fig. S5) appeared very similar to plain untreated cotton with a slightly smoother appearance. In addition, spindle-type networks were observed on the cotton fiber surface. These networks may increase the surface area for protein immobilization when compared with that of the APTES approach. The surfaces of cellulose fibers after further modification with lysozyme and HM-1 were also examined by SEM (Figs. 3e,f and S5). No macroscale changes of cross- 

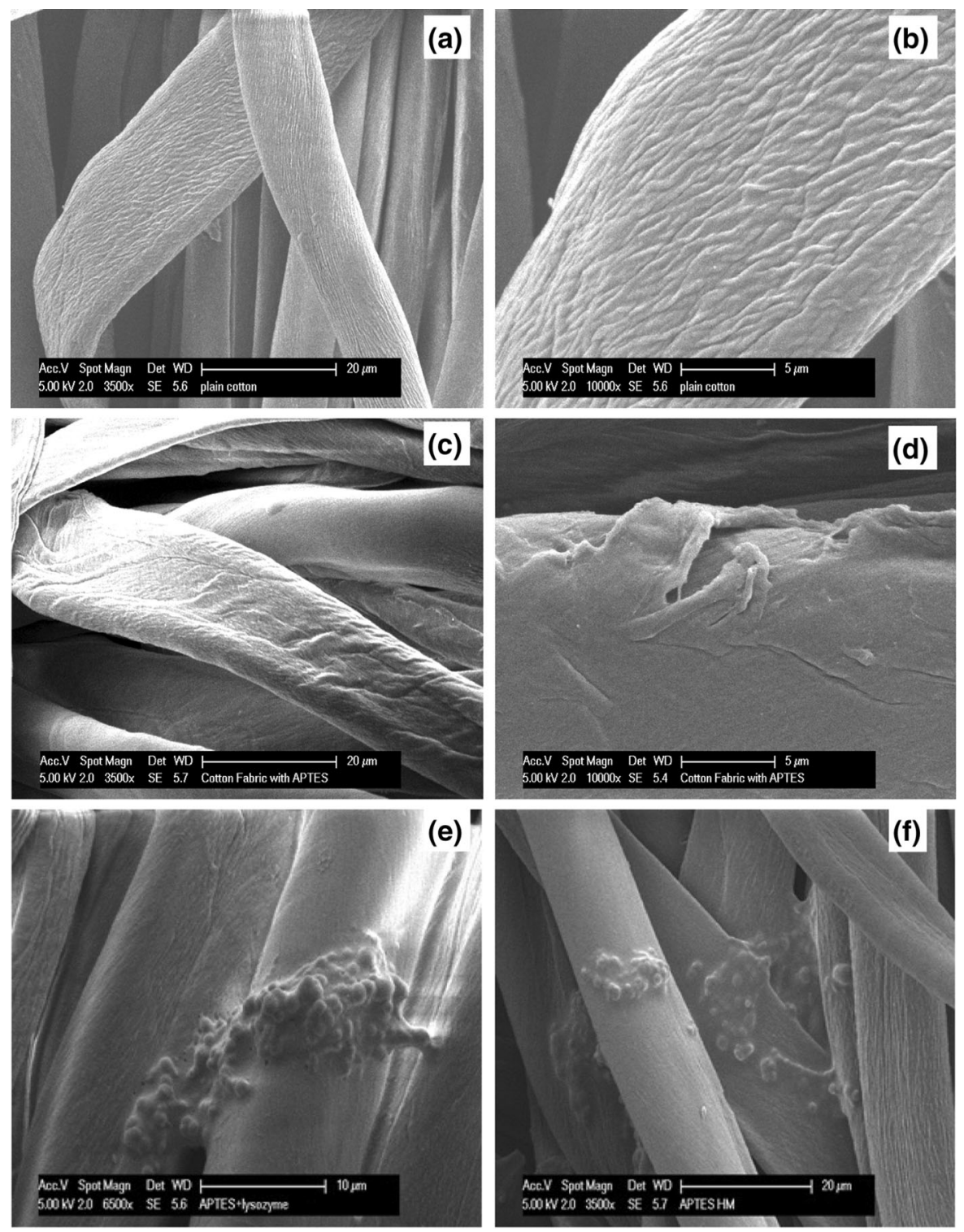

Fig. 3 SEM images of surface treated cotton swatches. a Surface of plain cotton without treatment. b Higher magnification view of plain cotton. c APTES treated cotton surface. d Higher magnification of the APTES protective coating

linker treated fiber surfaces were observed following treatment with either protein. However, small regions of the fibers were covered with aggregates, which are likely to be proteinaceous material that has deposited onto the cross-linker coated fibers because of possible inter-protein conjugation and/or nucleated protein aggregation induced by immobilization or dehydration during surface preparation, which has been illustrating a deformation. e Lysozyme and APTES treated cotton fibers. f HM-1 and APTES treated cotton fibers. For e and f proteinaceous aggregates are observed

observed previously for proteins (Sethuraman and Belfort 2005; Wu et al. 2013).

Antimicrobial activities of surface functionalized cotton samples

Lysozyme and HM-1 coated swatch surfaces were tested for antimicrobial activity (Fig. 4, Tables S1$\mathrm{S} 2)$. Lysozyme immobilized with the citric acid linker 


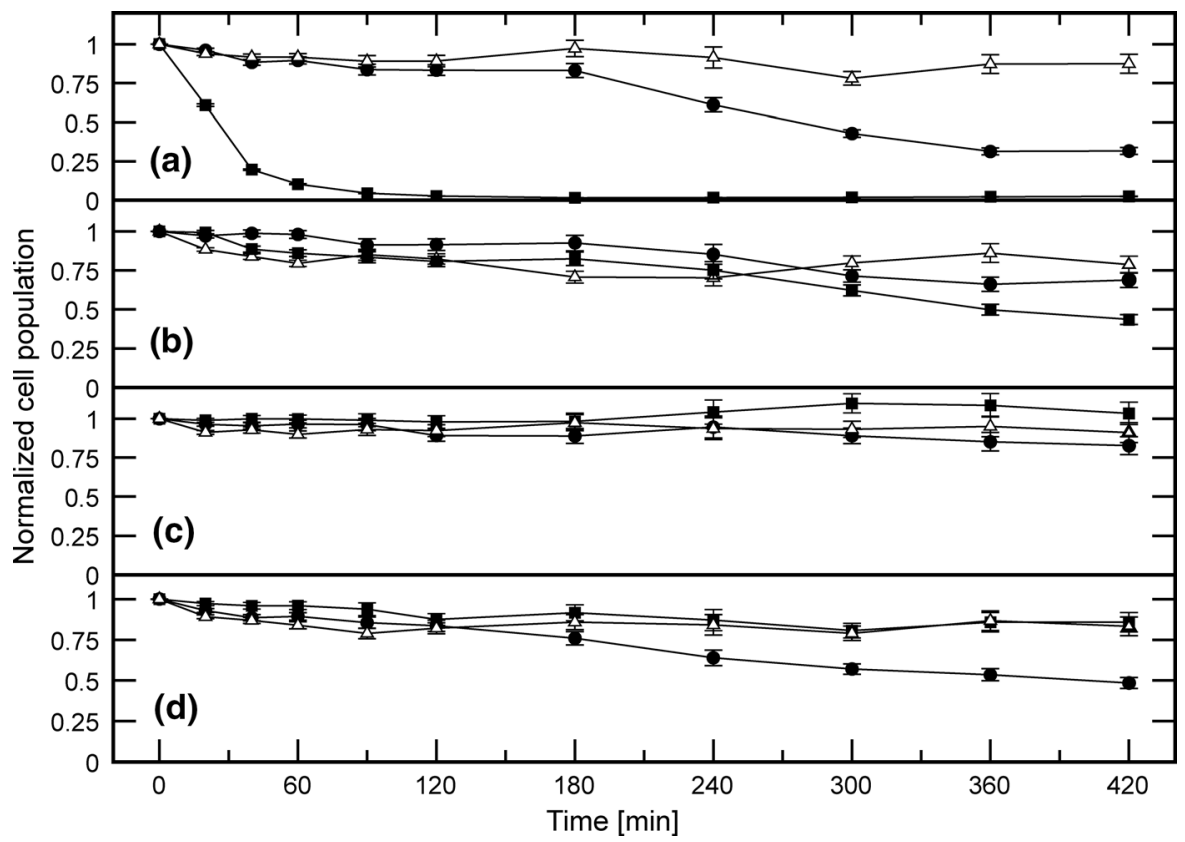

Fig. 4 Antimicrobial activity of the coated cotton swatches. Antibacterial activities of lysozyme (squares) and HM-1 (circles) functionalized surfaces against B. subtilis using a citric acid or APTES $\mathbf{b}$ as the coupling agent. Antibacterial activities of lysozyme (squares) and HM-1 (circles) functionalized surfaces against $E$. coli using $\mathbf{c}$ citric acid or APTES $\mathbf{d}$ as

showed the strongest activity against $B$. subtilis with cell viability lost after $\sim 100 \mathrm{~min}$ (Fig. 4a). APTESimmobilized lysozyme swatches were not as effective at reducing cell viability (Fig. 4b), possibly because of lower stability of the APTES coating. The citric acidimmobilized HM-1 surface was less potent in killing B. subtilis when compared with the lysozyme coated surfaces; nonetheless, a 70\% reduction in cell viability was reached after $420 \mathrm{~min}$ incubation. APTES-immobilized HM-1 was also not as effective as the citric acid equivalent, with only $30 \%$ reduction in cell viability after $420 \mathrm{~min}$ incubation. In contrast to activity against $B$. subtilis, surface coatings with lysozyme showed negligible activity against $E$. coli (Fig. 4c). Only the APTES immobilized HM-1 fibers (Fig. 4d) were effective against E. coli with $\sim 50 \%$ reduction in cell viability measured after $420 \mathrm{~min}$.

Based on the single coatings, we postulated that coating the surfaces with both proteins should provide an effective antimicrobial surface capable of inhibiting both Gram-positive and Gram-negative cells. The results showed that cotton swatches immobilized with HM-1 and lysozyme acquired the advantages of both proteins, the coupling agent. The open triangle symbols in each panel represent swatch coatings with only the coupling agent. Cell growth for each sample was normalized against cell growth in the presence of untreated cotton swatches. Errors are from three independent experiments

with both cell types showing a noticeable reduction in cell viability over the incubation period. In particular, the citric acid immobilized protein surface prevented $B$. subtilis cell survival, with cell viability reduced to zero after 360 min incubation (Fig. 5a, Tables S3-S4).

Interestingly, the dual coating was not as efficient as the citric acid immobilized lysozyme coated swatch, suggesting that HM-1 may interfere with lysozyme activity, or a lower amount of lysozyme is immobilized to the swatch because both proteins compete for the same available chemical cross-linker sites. This was not observed for the APTES immobilized proteins against E. coli (Fig. 5b) because the reduction in cell viability for the dual coating was very similar to the HM-1 only coating (Fig. 4d). Thus, under the chosen conditions for dual protein immobilization lysozyme did not appear to affect HM-1 immobilization and/or activity.

Morphology of the fibers following incubation with bacteria

The effects of incubating bacteria cells with the lysozyme coated swatches and dual coated swatches 


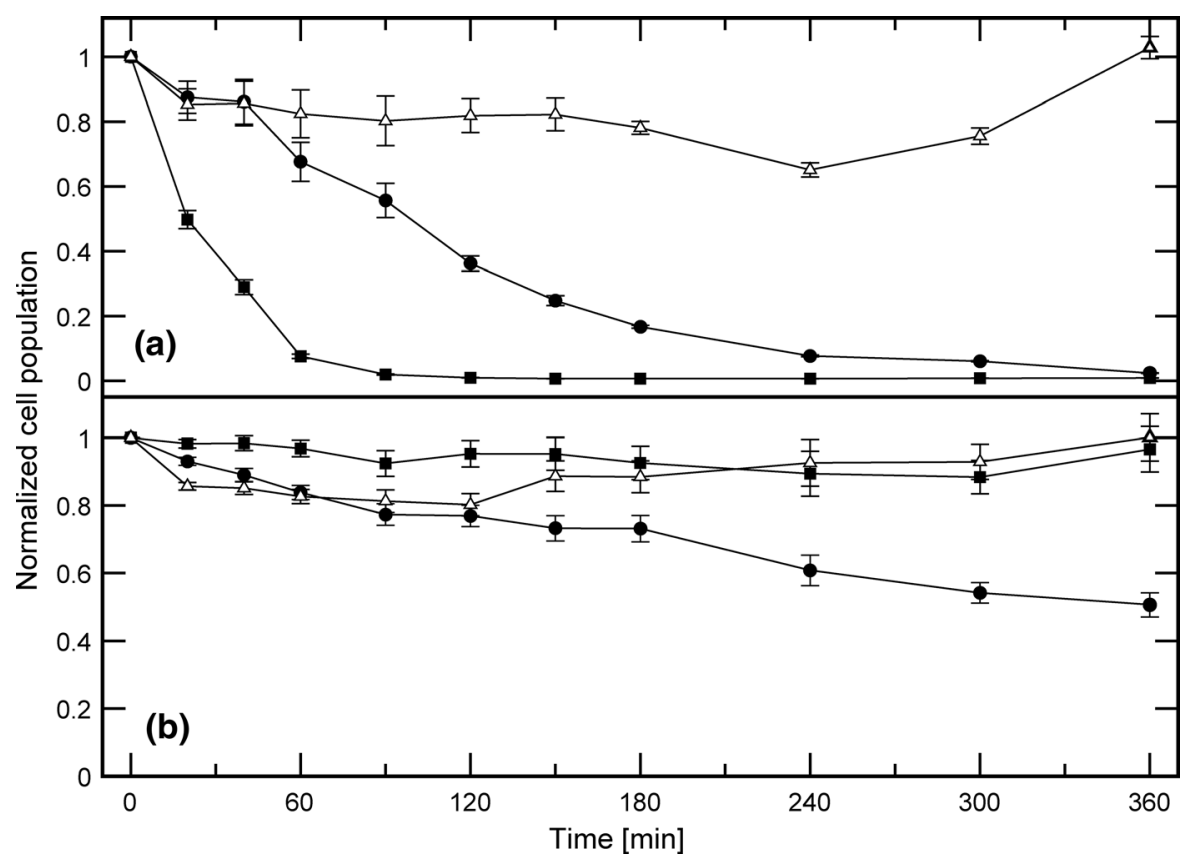

Fig. 5 Antibacterial activity of dual coated cotton swatches. a Antibacterial activities of cotton swatches treated with citric acid and both proteins (circles), citric acid and lysozyme (squares) and citric acid only (open symbols) against B. subtilis. b Antibacterial activities of cotton swatches treated with APTES

were examined by ESEM (Fig. 6). The images indicated that the number and morphology of the cells attached to the fibers varied and was dependent on the type of fiber coating. B. subtilis cells that had adhered to the untreated swatches appeared to have normal morphology (Fig. 6a), i.e., rod-shaped and $\sim 6 \mu \mathrm{m}$ in length. Cell morphologies of B. subtilis cells interacting with APTES immobilized lysozyme cotton fibers appeared shorter, with uneven membrane surfaces, suggestive of cell wall damage caused by lysozyme activity (Fig. 6b). ESEM images of B. subtilis incubated with citric acid immobilized lysozyme cotton fibers showed cells with severely deformed and perforated cell morphologies (Fig. 6c). The amount of cellular material attached to the citric acid immobilized lysozyme fibers was significantly less than that observed in other samples, suggesting the surface was effective at killing the bacteria and a lower number of cells remained adhered to the swatches (Fig. S6). The ESEM images of citric acid and APTES cross-linked lysozyme swatches support the bioassay results, which showed greater activity of the citric acid immobilized lysozyme cotton swatches when compared with the and both proteins (circles), APTES and lysozyme (squares) and APTES only (open symbols) against $E$. coli. Cell growth for each sample was normalized against cell growth in the presence of untreated cotton swatches. Errors are derived from three independent experiments

results using APTES as the cross linker. The cellular morphology of E. coli cells that colonized critic acid immobilized lysozyme fibers appeared normal (Fig. 6e) when compared with that of the control (Fig. S6e) and support the bioassay results that showed immobilized lysozyme was ineffective at preventing E. coli growth.

Both cell types readily colonized the dual coated surface in greater number (Fig. S6c, d) when compared with that of the negative controls (Figs. 6a, S6e). The morphology of $B$. subtilis cells attached to the dual coated surfaces was similar to the cells attached to the citric acid immobilized lysozyme coated surfaces, showing deformations and perforations indicative of cell wall disruption (Fig. 6d). E. coli cells attached to the dual coated surface aggregated to form complex cell clusters (Fig. 6f), which differ noticeably to the E. coli control (Fig. S6e). This aggregation of cells is a result of HM-1 activity, which has been shown to cause $E$. coli cells to aggregate in vitro (Jung et al. 2009). The adherence of cells to HM-1 coated fibers may explain the observed limited activity (Figs. 4 and 5) because bacteria avoid the 

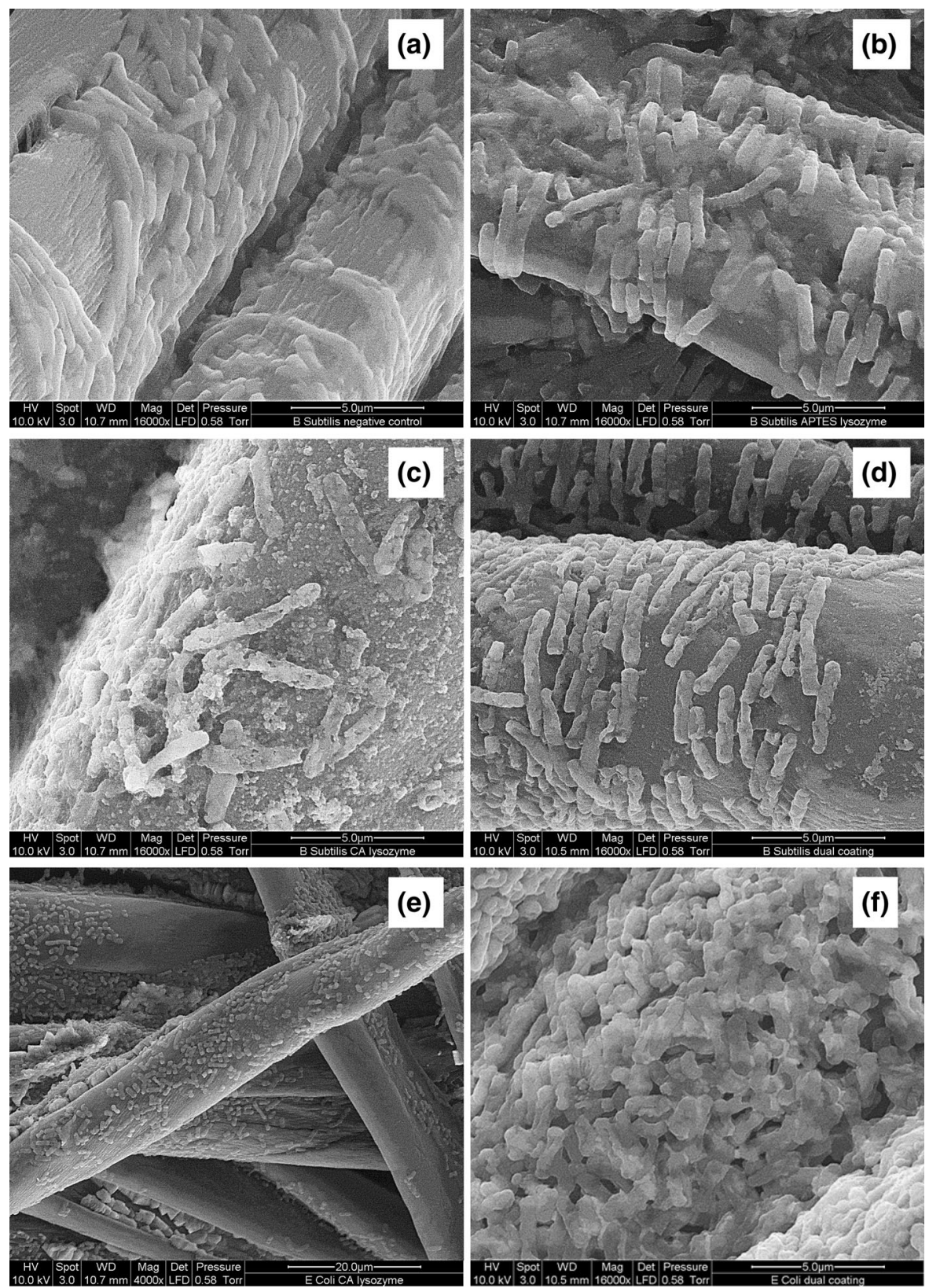

Fig. 6 ESEM images of surface treated cotton swatches following incubation with bacteria. a untreated, b APTES and lysozyme treated, $\mathbf{c}$ citric acid and lysozyme treated, and $\mathbf{d}$ citric acid, lysozyme and HM-1 treated cotton swatches incubated

inhibitory effects of the immobilized proteins, which renders the surface amenable to bacterial colonization. Thus, physical methods or antifouling approaches would be required to prevent the accumulation of unwanted cellular material on the cotton fibers. with B. subtilis. E. coli cells incubated with swatches coated with $\mathbf{e}$ citric acid and lysozyme and $\mathbf{f}$ citric acid, lysozyme and HM-1. Scale bar $=5 \mu \mathrm{m}$ in $\mathbf{a}-\mathbf{d}, \mathbf{f}$ and $20 \mu \mathrm{m}$ in $\mathbf{e}$

The activity of antimicrobial swatches following chemical and physical treatments

The surface morphology of functionalized cotton swatches following chemical and physical treatments were examined by SEM (Fig. S7). APTES treated 
cotton surfaces appeared irregular with degradation to the coatings and damage to the integrity of the fibers. In contrast, the citric acid protein coated surfaces showed minimal change following all three treatments.

Bioassays were conducted to test whether the physical changes to the fibers following treatment affected the biological activity of the swatches. Based on the most active antimicrobial surfaces found (Fig. 4) and to evaluate the largest possible effects of the treatments to activity, citric acid immobilized proteins against $B$. subtilis and APTES immobilized proteins against $E$. coli were tested. In general, the treated cotton swatches showed reduced activities against B. subtilis and E. coli (Fig. 7, Tables S5-S6). Only the citric acid immobilized lysozyme coated surface remained highly effective against $B$. subtilis, albeit at reduced activity following each treatment. Nonetheless, cell viability was reduced to $\sim 25 \%$ following the three treatments and incubation for $360 \mathrm{~min}$, and the observed decrease in viable cell population over the incubation period suggests that longer incubations may lead to complete loss of cell viability. These bioassay results are consistent with the SEM results, which showed that the citric acid coating was more resistant against the physical and chemical treatments. Interestingly, the antibacterial activity of the citric acid immobilized HM-1 swatch was clearly reduced following the sonication treatment, suggesting that HM-1 immobilization with citric acid is not as stable as lysozyme immobilized to the same crosslinker.

\section{Discussion}

In this report, two antimicrobial proteins were chemically cross-linked to cotton swatches using two different conjugation methods. ATR-FTIR and XPS were used to confirm immobilization of proteins to the surfaces, and SEM was used to visualize morphological features of the swatches following the conjugation reactions. Antibacterial functionalities of the modified coatings were examined by bioassays against two model bacteria, and the cellular morphologies of cells exposed to these coatings were visualized by ESEM.

To avoid loss of lysozyme activity when directly adsorbed to surfaces (Czeslik and Winter 2001; Vertegel et al. 2004), a reported aqueous-based method was used to surface immobilize the proteins through either primary amine containing residues, i.e., $\mathrm{N}$-terminus and Lys, or carboxyl containing residues, i.e., Glu and Asp (Edwards et al. 2011). Although this approach provides no control over protein orientations, stable covalent attachment yielded active antibacterial coatings with only a minor amount of physiosorbed lysozyme on citric acid coated fibers observed by ATR-FTIR (Fig. 1b).

The bioassay results (Figs. 4 and 5) and ESEM images (Figs. 6 and S6) demonstrated that the lysozyme functionalized surfaces were effective against Gram-positive B. subtilis but were much less active against $E$. coli because the peptidoglycan is protected by the outer membrane of Gram-negative bacteria. Moreover, the citric acid immobilized lysozyme (Fig. 4a) was noticeably more active than APTES immobilized lysozyme (Fig. 4c), which corroborates reported immobilization of lysozyme using the same chemistry and against Gram-positive Micrococcus lysodeikticus (Edwards et al. 2011). The likely lower loading of lysozyme to the APTES functionalized surface probably accounts, in part, for the weaker activity. Possible leaching of physiosorbed lysozyme on citric acid treated cotton swatches during the bioassays cannot be unequivocally excluded, and assays (e.g., ELISA) that detect and potentially quantify any possible protein leaching will be developed in future efforts that optimize the activity, immobilization chemistry, stability and durability of the coatings.

Cellulose esterified with citric acid provided $\mathrm{COOH}$ groups for amide bonding with protein $\mathrm{NH}_{2}$ groups. Lysozyme (PDB ID: 4ET8) and HM-1 (PDB ID: 2K35) structures were used to examine the preference of $\mathrm{NH}_{2}$ groups for coupling by calculating pKa values using PDB2PQR (Dolinsky et al. 2004) and accessible solvent areas using FreeSASA (Mitternacht 2016) (Tables S7 and S8). PDB2PQR calculated that all Lys side chain amino groups for both proteins have $\mathrm{pKa}$ values greater than 10 , whereas the $\mathrm{N}$-terminal amino group $\mathrm{pKa}$ values were calculated to be 7.4 (lysozyme) and 6.9 (HM-1). Given the $\mathrm{pH}$ of the protein coupling reaction was seven, it is conceivable that protein coupling to the $\mathrm{COOH}$ substrate via the solvent accessible N-terminal amino group of lysozyme was more efficient when compared with coupling via the six Lys residues, which have relative accessible surface areas (rASA) ranging between 


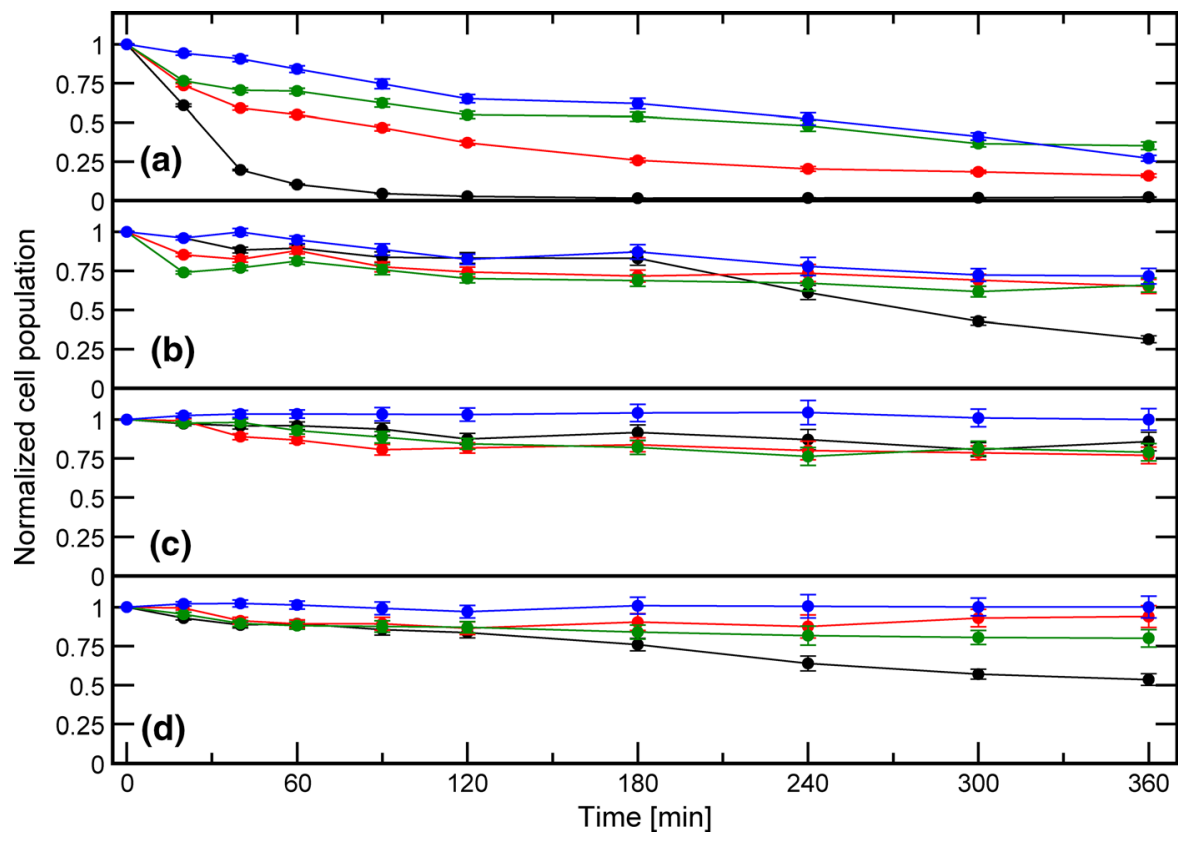

Fig. 7 Antimicrobial activity of the cotton swatches after sonication, heat and chemical treatment. a Citric acid immobilized lysozyme and $\mathbf{b}$ citric acid immobilized HM-1 functionalized cotton swatches incubated with $B$. subtilis. c APTES immobilized lysozyme and d APTES immobilized HM-1 functionalized cotton swatches incubated with E. coli. Data

$23.1 \%$ (K96) and 50.0\% (K116). This likely coupling position is supported by studies showing that the charged N- (K1, R5, R14) and C-termini (R125, R128) (termed N,C-terminus face) of lysozyme interact preferentially with negatively charged surfaces via electrostatic interactions (Dismer et al. 2008; KubiakOssowska et al. 2015; Kubiak-Ossowska and Mulheran 2010). Such orienting of the N-terminus to face the surface would facilitate amide bond formation between citric acid and the $\mathrm{N}$-terminal amino group, or the epsilon amino groups of K1 and K13 (Fig. 8a). Because the N,C-terminal face is located on an opposing face to the catalytic site, attachment via the $\mathrm{N}$-terminal region would orient the active cleft of lysozyme towards the solvent, ensuring optimal orientation for activity (Fig. 8a).

Protein was immobilized to $\mathrm{NH}_{2}$ groups of APTES via available $\mathrm{COOH}$ groups. Lysozyme has two glutamate and seven aspartate amino acids that have rASA values ranging between $15.8 \%$ (E35) and 58.6\% (D87). Thus, in addition to the likely lower lysozyme loading to the surface (Edwards et al. 2011), APTESprotein coupling likely yielded different orientations points in each figure are no physical or chemical treatment (black), sonication only (red), sonication and heating (green), and sonication, heating and soaking in ethanol (blue). Cell growth for each sample was normalized against cell growth in the presence of untreated cotton swatches. Errors are derived from three independent experiments

of the protein and some of these orientations may have reduced enzyme activity. Although the two catalytic residues of lysozyme, E35 and D52, have the lowest rASA of $15.8 \%$ and $18.0 \%$, respectively, it is likely that a fraction of the immobilized lysozyme is conjugated to APTES through these two residues, especially because E35 and D52 have the highest calculated $\mathrm{pKa}$ values of the acidic amino acids (Table S7). Conjugation through these two amino acids would render this fraction of lysozyme inactive. Moreover, attachment through D48 and D101, which are located on either side of the active site cleft, would orient the active site toward the surface, thereby hampering substrate binding (Fig. 8b). The combination of reduced enzyme loading and lower amounts of active immobilized lysozyme accounts for the lower activity of the APTES-lysozyme immobilized cotton swatches when compared with the activity of the citric acid immobilized lysozyme swatches (Fig. 4a,b). The observed lower stability of the APTES cross linking to cotton fibers may have also reduced the activity of these swatches (Fig. 2d), especially those swatches that underwent physical treatments (Fig. S7a,b). 

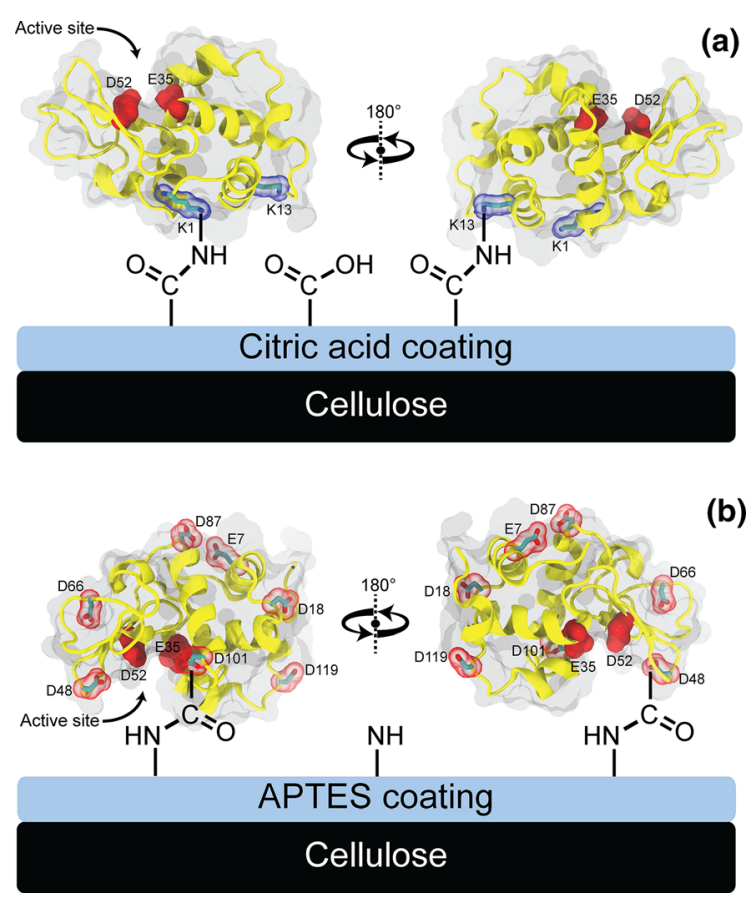

Fig. 8 Illustration of possible lysozyme orientations on the cellulose surface through different linkers. a K1 and K13 (blue transparent sphere and stick representations), which are part of the N,C-terminus face, attachment to cellulose via a citric acid linkage. Attachment through the $\mathrm{N}$-terminal amine group is also likely, but not shown. Attachment through these lysine side chains leaves the active cleft (E35 and D52 are represented as red space-filled models) facing towards the solvent to ensure efficient antibacterial activity. b Examples of attachment via amide linkages formed between D101 and D48 (red transparent sphere and stick representations) and APTES coating, which leaves the active cleft facing towards the surface, and thus reduces antibacterial activity. All acidic amino acids are shown as red transparent sphere and stick representations. VMD software (Humphrey et al. 1996) was used to prepare the lysozyme structures

Citric acid coupling of HM-1 to cotton swatches would also proceed favorably through the solvent accessible $\mathrm{N}$-terminus. Conjugation through any of the seven Lys side chain epsilon amino groups would also occur but less favorably than the N-terminal reaction. $\mathrm{K} 52$ and K37, which have the highest rASA of $93.7 \%$ and $85.7 \%($ rASA $=60.3 \%)$, respectively (Table S8), represent Lys residues most likely to react with the citric acid coated cotton swatches. APTES crosslinking of HM-1 would not directly affect the roles played by basic amino acids in the initial electrostatic attractions between HM-1 and the bacterial cell membranes, but particular couplings via one (or more) of the six Glu and Asp residues may yield protein orientations that affect antimicrobial activity. Nonetheless, APTES cross-linking of HM-1 gave rise to a surface with the highest activity against $E$. coli (Fig. 4d), suggesting that choice of chemistry used to tether HM-1 to the surface is a critical factor. The observation that total cell death was not achieved with HM-1 surface immobilization suggests that tethering reduced protein activity, the amount of HM-1 immobilized to the cotton swatches was too low, or particular coupling reactions gave rise to inactive HM-1, i.e., a tethered orientation that hampered activity. To overcome such possibilities, different linkers, the introduction of a spacer such as polyethylene glycol, or specific attachment should improve the activity profile of these HM-1 functionalized surfaces (Akers et al. 2017). Moreover, given the observed aggregation and attachment of cells on the fibers because of HM-1 activity (Figs. 6f and S6), the use of anti-adhesive polymers (Muszanska et al. 2011, 2014), such as block copolymers that form polymer brushes conjugated with HM-1 could yield a more active antimicrobial surface that does not experience potential fouling because of cell adhesion and aggregation.

Dual coating of the cotton swatch with HM-1 and lysozyme offers synergistic activity against Grampositive and Gram-negative bacteria (Fig. 5). The dual antimicrobial protein coating was less active than the lysozyme-only coating against B. subtilis (Fig. 5a), whereas similar activity against $E$. coli was observed between the HM-1-only and dual coatings (Figs. 4d and $5 \mathrm{~b}$ ). This suggests that under the conditions used in this study the citric acid immobilized lysozyme swatch had maximum activity and that immobilization of HM-1 and lysozyme to the citric acid activated swatch reduced the potential maximum lysozyme load, leading to a reduction in activity against $B$. subtilis. In contrast, maximum protein loading, and thus maximum activity, via APTES immobilization was not reached for either single or dual coating, which corroborates with the approximate measure of a lower protein amount immobilized to the surface. Further increases in activity may be obtained by using a different linker moiety (Hasan et al. 2020; ShriverLake et al. 2017) and combining the antibacterial activity with an antifouling or antibiofilm approach (Muszanska et al. 2014), which should improve the suitability of this approach for medical applications. Moreover, coatings that afford self-cleaning and 
improved durability to cotton fabrics, e.g., superhydrophobic coatings (Irfan et al. 2019; Lin et al. 2018; Rong et al. 2019; Xu et al. 2020), may be suitable for combined use with antimicrobial peptides and proteins, providing antibacterial coated cotton fabrics with long-term stability and greater activity. Additional experiments examining the stability of the dualcoated samples should facilitate development of more active coatings, as well as combining other antimicrobial proteins to create surfaces with broader, effective antibacterial activity. Nonetheless, the dual coating represents a promising result that supports the feasibility of developing a functionalized cotton wound dressing material using antimicrobial proteins and peptides to prevent biofilm formation against both Gram-positive and Gram-negative bacteria.

Durability and stability of antimicrobial fabrics are key parameters for assessing the performance of synthesized antimicrobial materials. The general cleaning procedure for medical dressing materials includes rinsing, heating and soaking in alcohol. By taking into consideration the sample size, the stability tests were designed accordingly. SEM images acquired from sonication, heat- and ethanol-treated surface functionalized cotton samples showed that the surface stability of APTES treated cotton swatches was noticeably worse than the citric acid treated swatches (Fig. S7). Damage and deformation to the APTES-protein treated cotton swatches was visible, whereas citric acid coated cotton fibers remained intact. This observation indicates that APTES may not be a suitable crosslinking agent for coating biopolymers to cellulose fibers under standard coating conditions. Bioassays of treated surface functionalized cotton samples revealed that only the citric acid and lysozyme treated cotton fabric maintained highly efficient antimicrobial activity against B. subtilis, whereas other surface functionalized samples lost most of their activity after treatments (Fig. 7). This result supports the observed stability of the citric acid network and indicates that lysozyme can tolerate the cleaning procedures, which is in agreement with studies showing that lysozyme is chemically and thermally stable (melting midpoint temperature of $75^{\circ} \mathrm{C}$ (Li-Blatter and Seelig 2019)) and remains partially active when heated above the melting temperature for short periods (i.e., minutes (Vilcacundo et al. 2018)), as used in this study $\left(100{ }^{\circ} \mathrm{C}\right.$, $60 \mathrm{~s})$. Moreover, heat treatment has been shown to change (rather than inactivate) the activity profile of lysozyme (Ibrahim et al. 1996) and modifications to lysozyme may improve thermal stability (Morgenstern et al. 2017). Thus, these attributes make lysozyme a potentially useful antimicrobial agent to use in coatings; although further characterization of the modified cotton fabrics such as tensile strength, abrasive resistance and laundering durability is required. The reduced HM-1 activity following treatments indicates that: (i) milder treatments are required when using HM-1 in cotton-coated applications; (ii) protein engineering or modification is needed to improve HM-1 stability; and (iii) the use of different immobilization chemistries may improve the activity of immobilized HM-1.

\section{Conclusions}

In summary, cotton fabrics immobilized with lysozyme and HM-1 were active against Gram-positive $B$. subtilis and Gram-negative E. coli bacteria. Although these two proteins target bacteria, and lysozyme is used widely as an authorized food preservative (E1105), in drugs, and recognized as being safe as a natural antibacterial agent by the US Food and Drug Administration, localized high concentrations, such as those generated when immobilizing proteins to surfaces, may cause cytotoxicity. Thus, possible cytotoxicity of the immobilized antibacterial proteins will be examined following further optimization of the immobilization chemistry. Such optimization may involve the use of other chemistries (Yi et al. 2020), including other acids such as phthalic acid (Dos Santos et al. 2018), lauric acid and malic acid to replace or react with the hydroxyl groups of cellulose, combining superhydrophobicity or antiadhesive capacity (Lin et al. 2018; Xu et al. 2020) with immobilization of antimicrobial proteins and forming antimicrobial protein/peptide clusters (Orlandin et al. 2019).

Dual coating with lysozyme and HM-1 offered a synergistic approach against the Gram-positive and Gram-negative bacteria, indicating that combinations of various other antimicrobial proteins and peptides should enable tailoring of the antimicrobial properties of fabrics for specific applications where particular bacteria thrive. The antimicrobial protein-treated cotton swatches had reduced activity following the cleaning procedures. Thus, efforts focusing on the use 
of different combinations of antimicrobial peptides and proteins and immobilization chemistry should lead to the development of coatings that are more durable against sterilization processes and thus suitable for long-term therapeutic use.

Acknowledgments The authors acknowledge technical support from Catherine Hobbis (Technical Services, Faculty of Engineering, The University of Auckland) for SEM and ESEM measurements, and Dr Dongmei Cao (Shared Instrument Facility, Louisiana State University) for assistance with XPS measurements. We thank Prof. Joachim Grötzinger and Dr. Sascha Jung from the Institute of Biochemistry, ChristianAlbrechts-Universität zu Kiel, for kindly providing the HM-1 expression construct.

Authors' contributions All authors contributed to the study conception and design. Material preparation, data collection and analysis were performed primarily by AYX with support from DJM and AJD. The first draft of the manuscript was written by AYX and all authors commented on previous versions of the manuscript. All authors read and approved the final manuscript.

Funding Open Access funding enabled and organized by Projekt DEAL. No funding was received for conducting this study.

Data Availability Not applicable.

Code availability Not applicable.

\section{Declarations}

Conflict of interest The authors have no conflicts of interest to declare that are relevant to the content of this article.

Ethics approval Not applicable.

Consent to participate Not applicable.

Consent for publication Not applicable.

Open Access This article is licensed under a Creative Commons Attribution 4.0 International License, which permits use, sharing, adaptation, distribution and reproduction in any medium or format, as long as you give appropriate credit to the original author(s) and the source, provide a link to the Creative Commons licence, and indicate if changes were made. The images or other third party material in this article are included in the article's Creative Commons licence, unless indicated otherwise in a credit line to the material. If material is not included in the article's Creative Commons licence and your intended use is not permitted by statutory regulation or exceeds the permitted use, you will need to obtain permission directly from the copyright holder. To view a copy of this licence, visit http://creativecommons.org/licenses/by/4.0/.

\section{References}

Akers PW, Dingley AJ, Swift S, Nelson ARJ, Martin J, McGillivray DJ (2017) Using neutron reflectometry to characterize antimicrobial protein surface coatings. J Phys Chem B 121:5908-5916

Arciola CR, Campoccia D, Montanaro L (2018) Implant infections: adhesion, biofilm formation and immune evasion. Nat Rev Microbiol 16:397-409

Balamurugan S, Obubuafo A, McCarley RL, Soper SA, Spivak DA (2008) Effect of linker structure on surface density of aptamer monolayers and their corresponding protein binding efficiency. Anal Chem 80:9630-9634

Battersby AJ, Khara J, Wright VJ, Levy O, Kampmann B (2016) Antimicrobial proteins and peptides in early life: Ontogeny and translational opportunities. Front Immunol 7:309

Campbell J (2011) High-throughput assessment of bacterial growth inhibition by optical density measurements. Curr Protoc Chem Biol 2:195-208

Castellano M, Gandini A, Fabbri P, Belgacem MN (2004) Modification of cellulose fibres with organosilanes: under what conditions does coupling occur? J Colloid Interface Sci 273:505-511

Chiereghin A, Felici S, Gibertoni D, Foschi C, Turello G, Piccirilli G, Gabrielli L, Clerici P, Landini MP, Lazzarotto T (2020) Microbial contamination of medical staff clothing during patient care activities: performance of decontamination of domestic versus industrial laundering procedures. Curr Microbiol 77:1159-1166

Czeslik C, Winter R (2001) Effect of temperature on the conformation of lysozyme adsorbed to silica particles. Phys Chem Chem Phys 3:235-239

Davidson DJ, Spratt D, Liddle AD (2019) Implant materials and prosthetic joint infection: the battle with the biofilm. EFORT Open Rev 4:633-639

Davis GS, Sevdalis N, Drumright LN (2014) Spatial and temporal analyses to investigate infectious disease transmission within healthcare settings. J Hosp Infect 86:227-243

Dismer F, Petzold M, Hubbuch J (2008) Effects of ionic strength and mobile phase $\mathrm{pH}$ on the binding orientation of lysozyme on different ion-exchange adsorbents. J Chromatogr A $1194: 11-21$

Dolinsky TJ, Nielsen JE, McCammon JA, Baker NA (2004) PDB2PQR: an automated pipeline for the setup of PoissonBoltzmann electrostatics calculations. Nucleic Acids Res 32:W665-W667

Dos Santos SL, De Oliveira CJ, De Sousa Bezerra RD, Da Silva MS, Ferreira FJL, Osajima JA, Da Silva Filho EC (2018) Potential of cellulose functionalized with carboxylic acid as biosorbent for the removal of cationic dyes in aqueous solution. Molecules 23:743

Duan P, Xu Q, Zhang X, Chen J, Zheng W, Li L, Yang J, Fu F, Diao H, Liu X (2020) Naturally occurring betaine grafted on cotton fabric for achieving antibacterial and anti-protein adsorption functions. Cellulose 27:6603-6615

Edwards JV, Eggleston G, Yager DR, Cohen IK, Diegelmann RF, Bopp AF (2002) Design, preparation and assessment of citrate-linked monosaccharide cellulose conjugates with elastase-lowering activity. Carbohydr Polym 50:305-314 
Edwards JV, Prevost N, Condon B, French A (2011) Covalent attachment of lysozyme to cotton/cellulose materials: protein verses solid support activation. Cellulose 18:1239-1249

El-Tahlawy K, El-Nagar K, Elhendawy AG (2007) Cyclodextrin-4 hydroxy benzophenone inclusion complex for UV protective cotton fabric. J Text Inst 98:453-462

Emam HE (2019) Antimicrobial cellulosic textiles based on organic compounds. 3 Biotech 9:29

Faccio G (2018) From protein features to sensing surfaces. Sensors 18:1204

Fernandes SCM, Sadocco P, Alonso-Varona A, Palomares T, Eceiza A, Silvestre AJD, Mondragon I, Freire CSR (2013) Bioinspired antimicrobial and biocompatible bacterial cellulose membranes obtained by surface functionalization with aminoalkyl groups. ACS Appl Mater Interfaces 5:3290-3297

Fouda MMG, Fahmy HM (2011) Multifunctional finish and cotton cellulose fabric. Carbohydr Polym 86:625-629

Frone AN, Panaitescu DM, Chiulan I, Nicolae CA, Casarica A, Gabor AR, Trusca R, Damian CM, Purcar V, Alexandrescu E, Stanescu PO (2018) Surface treatment of bacterial cellulose in mild, eco-friendly conditions. Coatings 8:221

Gunda NSK, Singh M, Norman L, Kaur K, Mitra SK (2014) Optimization and characterization of biomolecule immobilization on silicon substrates using (3-aminopropyl)triethoxysilane (APTES) and glutaraldehyde linker. Appl Surf Sci 305:522-530

Hale JD, Hancock RE (2007) Alternative mechanisms of action of cationic antimicrobial peptides on bacteria. Expert Rev Anti Infect Ther 5:951-959

Hasan A, Lee K, Tewari K, Pandey LM, Messersmith PB, Faulds K, Maclean M, Lau KHA (2020) Surface design for immobilization of an antimicrobial peptide mimic for efficient anti-biofouling. Chemistry 26:5789-5793

Humphrey W, Dalke A, Schulten K (1996) VMD: visual molecular dynamics. J Mol Graph 14:33-38

Hyldgaard M, Mygind T, Vad BS, Stenvang M, Otzen DE, Meyer RL (2014) The antimicrobial mechanism of action of epsilon-poly-L-lysine. Appl Environ Microbiol 80:7758-7770

Ibrahim HR, Higashiguchi S, Juneja LR, Kim M, Yamamoto T (1996) A structural phase of heat-denatured lysozyme with novel antimicrobial action. J Agric Food Chem 44:1416-1423

Irfan M, Polonskyi O, Hinz A, Mollea C, Bosco F, Strunskus T, Balagna C, Perero S, Faupel F, Ferraris M (2019) Antibacterial, highly hydrophobic and semi transparent $\mathrm{Ag} /$ plasma polymer nanocomposite coating on cotton fabric obtained by plasma based co-deposition. Cellulose 26:8877-8894

Jiang LL, Ng IHL, Hou YA, Li DL, Tan LWL, Ho HJA, Chen MIC (2018a) Infectious disease transmission: survey of contacts between hospital-based healthcare workers and working adults from the general population. J Hosp Infect 98:404-411

Jiang J, Pi J, Cai J (2018b) The advancing of zinc oxide nanoparticles for biomedical applications. Bioinorg Chem Appl 2018:1062562

Jung S, Dingley AJ, Augustin R, Anton-Erxleben F, Stanisak M, Gelhaus C, Gutsmann T, Hammer MU, Podschun R,
Bonvin AM, Leippe M, Bosch TC, Grötzinger J (2009) Hydramacin-1, structure and antibacterial activity of a protein from the basal metazoan Hydra. J Biol Chem 284:1896-1905

Katoh I, Tanabe F, Kasai H, Moriishi K, Shimasaki N, Shinohara K, Uchida Y, Koshiba T, Arakawa S, Morimoto M (2019) Potential risk of virus carryover by fabrics of personal protective gowns. Front Public Health 7:121

Kubiak-Ossowska K, Cwieka M, Kaczynska A, Jachimska B, Mulheran PA (2015) Lysozyme adsorption at a silica surface using simulation and experiment: effects of $\mathrm{pH}$ on protein layer structure. Phys Chem Chem Phys 17:24070-24077

Kubiak-Ossowska K, Mulheran PA (2010) Mechanism of hen egg white lysozyme adsorption on a charged solid surface. Langmuir 26:15954-15965

Kuppusamy R, Willcox M, Black DS, Kumar N (2019) Short cationic peptidomimetic antimicrobials. Antibiotics 8:44

Li W, Separovic F, O'Brien-Simpson NM, Wade JD (2021) Chemically modified and conjugated antimicrobial peptides against superbugs. Chem Soc Rev 50:4932-4973

Li-Blatter X, Seelig J (2019) Thermal and chemical unfolding of lysozyme. Multistate Zimm-Bragg theory versus two-state model. J Phys Chem B 123:10181-10191

Lin J, Chen X, Chen C, Hu J, Zhou C, Cai X, Wang W, Zheng C, Zhang P, Cheng J, Guo Z, Liu H (2018) Durably antibacterial and bacterially antiadhesive cotton fabrics coated by cationic fluorinated polymers. ACS Appl Mater Interfaces 10:6124-6136

Magana M, Pushpanathan M, Santos AL, Leanse L, Fernandez M, Ioannidis A, Giulianotti MA, Apidianakis Y, Bradfute S, Ferguson AL, Cherkasov A, Seleem MN, Pinilla C, de la Fuente-Nunez C, Lazaridis T, Dai T, Houghten RA, Hancock REW, Tegos GP (2020) The value of antimicrobial peptides in the age of resistance. Lancet Infect Dis 20:e216-e230

Makowski T (2020) Hydrophobization of cotton fabric with silanes with different substituents. Cellulose 27:1-9

Malik E, Dennison SR, Harris F, Phoenix DA (2016) pH dependent antimicrobial peptides and proteins, their mechanisms of action and potential as therapeutic agents. Pharmaceuticals 9:67

Mangoni ML, McDermott AM, Zasloff M (2016) Antimicrobial peptides and wound healing: biological and therapeutic considerations. Exp Dermatol 25:167-173

Meftahi A, Khajavi R, Rashidi A, Rahimi MK, Bahador A (2018) Preventing the collapse of 3D bacterial cellulose network via citric acid. J Nanostruct Chem 8:311-320

Mitternacht S (2016) FreeSASA: an open source C library for solvent accessible surface area calculations. F1000Res 5:189

Mohamad NR, Marzuki NH, Buang NA, Huyop F, Wahab RA (2015) An overview of technologies for immobilization of enzymes and surface analysis techniques for immobilized enzymes. Biotechnol Biotechnol Equip 29:205-220

Morais DS, Guedes RM, Lopes MA (2016) Antimicrobial approaches for textiles: from research to market. Materials 9:498

Morgenstern J, Baumann P, Brunner C, Hubbuch J (2017) Effect of PEG molecular weight and PEGylation degree on the 
physical stability of PEGylated lysozyme. Int J Pharm 519:408-417

Mukherjee J, Gupta MN (2015) Increasing importance of protein flexibility in designing biocatalytic processes. Biotechnol Rep 6:119-123

Muszanska A, Busscher H, Herrmann A, van der Mei H, Norde W (2011) Pluronic-lysozyme conjugates as anti-adhesive and antibacterial bifunctional polymers for surface coating. Biomaterials 32:6333-6341

Muszanska AK, Rochford ET, Gruszka A, Bastian AA, Busscher HJ, Norde W, van der Mei HC, Herrmann A (2014) Antiadhesive polymer brush coating functionalized with antimicrobial and RGD peptides to reduce biofilm formation and enhance tissue integration. Biomacromolecules 15:2019-2026

Oda Y, Kanaoka S, Sato T, Aoshima S, Kuroda K (2011) Block versus random amphiphilic copolymers as antibacterial agents. Biomacromolecules 12:3581-3591

Orlandin A, Dolcet P, Biondi B, Hilma G, Coman D, Oancea S, Formaggio F, Peggion C (2019) Covalent graft of lipopeptides and peptide dendrimers to cellulose fibers. Coatings 9:606

Penuelas-Urquides K, Villarreal-Trevino L, Silva-Ramirez B, Rivadeneyra-Espinoza L, Said-Fernandez S, de Leon MB (2013) Measuring of Mycobacterium tuberculosis growth: a correlation of the optical measurements with colony forming units. Braz J Microbiol 44:287-289

Rong L, Liu H, Wang B, Mao Z, Xu H, Zhang L, Zhong Y, Feng $X$, Sui X (2019) Durable antibacterial and hydrophobic cotton fabrics utilizing enamine bonds. Carbohydr Polym 211:173-180

Rovira J, Domingo JL (2019) Human health risks due to exposure to inorganic and organic chemicals from textiles: a review. Environ Res 168:62-69

Schrand AM, Rahman MF, Hussain SM, Schlager JJ, Smith DA, Syed AF (2010) Metal-based nanoparticles and their toxicity assessment. Wiley Interdiscip Rev Nanomed Nanobiotechnol 2:544-568

Seo MD, Won HS, Kim JH, Mishig-Ochir T, Lee BJ (2012) Antimicrobial peptides for therapeutic applications: a review. Molecules 17:12276-12286

Sethuraman A, Belfort G (2005) Protein structural perturbation and aggregation on homogeneous surfaces. Biophys $\mathrm{J}$ 88:1322-1333

Shriver-Lake LC, Anderson GP, Taitt CR (2017) Effect of linker length on cell capture by poly(ethylene glycol)-immobilized antimicrobial peptides. Langmuir 33:2878-2884

Sobczak M, Dębek C, Olędzka E, Kozłowski R (2013) Polymeric systems of antimicrobial peptides - strategies and potential applications. Molecules 18:14122-14137

Tan L-Y, Sin LT, Bee S-T, Ratnam CT, Woo K-K, Tee T-T, Rahmat AR (2019) A review of antimicrobial fabric containing nanostructures metal-based compound. J Vinyl Addit Technol 25:E3-E27

Tanabe F, Uchida Y, Arakawa S, Morimoto M (2020) Increased adhesion of methicillin-resistant Staphylococcus aureus to the surface of personal protective clothing damaged by friction during nursing action. Am J Infect Control 48:416-419
Torres MDT, Sothiselvam S, Lu TK, de la Fuente-Nunez C (2019) Peptide design principles for antimicrobial applications. J Mol Biol 431:3547-3567

Vertegel AA, Siegel RW, Dordick JS (2004) Silica nanoparticle size influences the structure and enzymatic activity of adsorbed lysozyme. Langmuir 20:6800-6807

Vilcacundo R, Méndez P, Reyes W, Romero H, Pinto A, Carrillo W (2018) Antibacterial activity of hen egg white lysozyme denatured by thermal and chemical treatments. Sci Pharm $86: 48$

Weir A, Westerhoff P, Fabricius L, Hristovski K, von Goetz N (2012) Titanium dioxide nanoparticles in food and personal care products. Environ Sci Technol 46:2242-2250

Wittmann C, Hock B (1989) Improved enzyme immunoassay for the analysis of s-triazines in water samples. Food Agric Immunol 1:211-224

Wu X, Fraser K, Zha J, Dordick JS (2018) Flexible peptide linkers enhance the antimicrobial activity of surface-immobilized bacteriolytic enzymes. ACS Appl Mater Interfaces 10:36746-36756

Wu Y, Wang K, Buschle-Diller G, Liles MR (2013) Fiber formation by dehydration-induced aggregation of albumin. J Appl Polym Sci 129:3591-3600

Xiao M, Jasensky J, Gerszberg J, Chen J, Tian J, Lin T, Lu T, Lahann J, Chen Z (2018) Chemically immobilized antimicrobial peptide on polymer and self-assembled monolayer substrates. Langmuir 34:12889-12896

Xu Q, Shen L, Duan P, Zhang L, Fu F, Liu X (2020) Superhydrophobic cotton fabric with excellent healability fabricated by the "grafting to" method using a diblock copolymer mist. Chem Eng J 379:122401

Yang L, Zhan C, Huang X, Hong L, Fang L, Wang W, Su J (2020) Durable antibacterial cotton fabrics based on natural borneol-derived anti-MRSA agents. Adv Healthc Mater 9:e2000186

Yeaman MR, Yount NY (2003) Mechanisms of antimicrobial peptide action and resistance. Pharmacol Rev 55:27-55

Yi T, Zhao H, Mo Q, Pan D, Liu Y, Huang L, Xu H, Hu B, Song H (2020) From cellulose to cellulose nanofibrils-a comprehensive review of the preparation and modification of cellulose nanofibrils. Materials 13:5062

Yilmaz F (2020) Application of Glycyrrhiza glabra L. root as a natural antibacterial agent in finishing of textile. Ind Crop Prod 157:112899

Y1lmaz F, Bahtiyari Mİ (2020) Antibacterial finishing of cotton fabrics by dyeing with olive tree leaves fallen during olive harvesting. J Clean Prod 270:122068

Yılmaz F, Koçak ÖF, Özgeriş FB, Şapçı Selamoğlu H, Vural C, Benli H, Bahtiyari Mİ (2020) Use of Viburnum Opulus L. (Caprifoliaceae) in dyeing and antibacterial finishing of cotton. J Nat Fibers 17:1081-1088

Yue Y, Han J, Han G, Zhang Q, French AD, Wu Q (2015) Characterization of cellulose I/II hybrid fibers isolated from energycane bagasse during the delignification process: morphology, crystallinity and percentage estimation. Carbohydr Polym 133:438-447

Publisher's Note Springer Nature remains neutral with regard to jurisdictional claims in published maps and institutional affiliations. 